\title{
Pharmacologic Evidence for a Putative Conserved Allosteric Site on Opioid Receptors
}

\author{
Kathryn E. Livingston, ${ }^{1}$ M. Alexander Stanczyk, Neil T. Burford, Andrew Alt, ${ }^{2}$ \\ Meritxell Canals, and John R. Traynor \\ Department of Pharmacology and Edward F. Domino Research Center, University of Michigan, Ann Arbor, Michigan (K.E.L., \\ M.A.S., J.R.T.); Research and Development/Discovery, Bristol-Myers Squibb Company, Wallingford, Connecticut (N.T.B., A.A.); \\ and Monash Institute of Pharmaceutical Sciences, Monash University, Parkville, Victoria, Australia (M.C.)
}

Received June 2, 2017; accepted November 27, 2017

\section{ABSTRACT}

Allosteric modulators of G protein-coupled receptors, including opioid receptors, have been proposed as possible therapeutic agents with enhanced selectivity. BMS-986122 is a positive allosteric modulator (PAM) of the $\mu$-opioid receptor ( $\mu$-OR). BMS-986187 is a structurally distinct PAM for the $\delta$-opioid receptor $(\delta$-OR) that has been reported to exhibit 100 -fold selectivity in promoting $\delta$-OR over $\mu$-OR agonism. We used ligand binding and second-messenger assays to show that BMS-986187 is an effective PAM at the $\mu$-OR and at the $\kappa$-opioid receptor $(\kappa-\mathrm{OR})$, but it is ineffective at the nociceptin receptor. The affinity of BMS-986187 for $\delta$-ORs and $\kappa$-ORs is approximately 20 - to 30 -fold higher than for $\mu$-ORs, determined using an allosteric ternary complex model. Moreover, we provide evidence, using a silent allosteric modulator as an allosteric antagonist, that BMS-986187 and BMS-986122 bind to a similar region on all three traditional opioid receptor types $(\mu-\mathrm{OR}, \delta$-OR, and $\kappa$-OR). In contrast to the dogma surrounding allosteric modulators, the results indicate a possible conserved allosteric binding site across the opioid receptor family that can accommodate structurally diverse molecules. These findings have implications for the development of selective allosteric modulators.

\section{Introduction}

Allosteric modulation of $\mathrm{G}$ protein-coupled receptors (GPCRs) is a promising new avenue to develop safer drugs. With this aim in mind, we have discovered positive allosteric modulators (PAMs) of both $\mu$-opioid $(\mu$-OR) and $\delta$-opioid $(\delta$-OR) receptors. These allosteric modulators (Burford et al., 2013, 2015; Livingston and Traynor, 2014; Bisignano et al., 2015 ) bind to a site on the receptor distinct from the orthosteric site for endogenous opioid peptides and traditional opiate analgesics drugs to enhance the affinity and/or efficacy of various orthosteric ligands in an agonist-dependent manner, described as probe dependence. BMS-986122 (Fig. 1) is selective for $\mu$-OR and has no detectable activity at the closely related $\delta$-OR (Burford et al., 2013), whereas the $\delta$-OR PAM, BMS-986187 (Fig. 1), possesses a 100-higher potency at $\delta$-OR over $\mu$-OR (Burford et al., 2015).

This work was supported by National Institutes of Health, National Institute on Drug Abuse Institute [Grants R01 DA39997 and T32 DA007267] and an EDGE Fellowship from the Endowment for the Basic Sciences, University of Michigan.

${ }^{1}$ Current affiliation: Department of Psychiatry, Genentech Hall, San Francisco, California.

${ }^{2}$ Current affiliation: Arvinas Inc, New Haven, Connecticut.

https://doi.org/10.1124/mol.117.109561.
The selectivity of the PAMs is not surprising as enhanced selectivity is one of the touted benefits of allosteric modulation of GPCRs over traditional orthosteric activation. Ligandbinding domains were evolved and maintained to bind endogenous ligands, whereas sites for small allosteric ligands face less evolutionary pressure to be conserved. Therefore, even closely related receptors of the same family that have very similar orthosteric binding pockets can have different allosteric binding sites (for review, see Conn et al., 2009). For example, the $\mu$ - and $\delta$-ORs share more than $64 \%$ sequence identity and are nearly identical in the transmembrane (TM) domains (Stevens, 2009), with highly conserved orthosteric binding pockets as determined from multiple inactive-state crystal structures (Lin et al., 2009; Manglik et al., 2012; Fenalti et al., 2014), as well as an active-state structure of $\mu$-OR (Huang et al., 2015). In addition, the opioid peptides Leu- and Met-enkephalin are endogenous ligands for both receptors, and the signaling pathways downstream of the receptors are quite similar (Chen et al., 1993). On the other hand, the allosteric ligands discovered to date for the two receptors are highly structurally distinct (Fig. 1).

In previous work, we have demonstrated that the action of BMS-986122 at $\mu$-OR involves a disruption with the binding of $\mathrm{Na}^{+}$ions (Livingston and Traynor, 2014) that modulate the activity of many class A GPCRs, including the opioid receptor

ABBREVIATIONS: AC, adenylate cyclase; $\mathrm{CHO}$, Chinese hamster ovary (cells); DPN, diprenorphine; FBS, fetal bovine serum; GPCR, G protein coupled receptor; GTP $\gamma$ S, guanosine-5'-O-(3-thio)triphosphate; HEK, human embryonic kidney (cells); mAchR, muscarinic acetylcholine receptor; NOPR, nociceptin receptor; $\delta$-OR, delta opioid receptor; $\kappa$-OR, kappa opioid receptor; $\mu$-OR, mu opioid receptor; PK, Pro-Link; PAM, positive allosteric modulator; SAM, silent allosteric modulator; TM, transmembrane. 


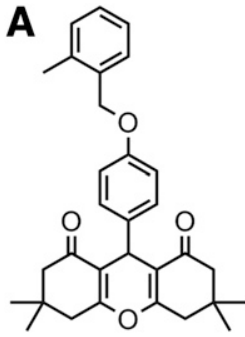

B
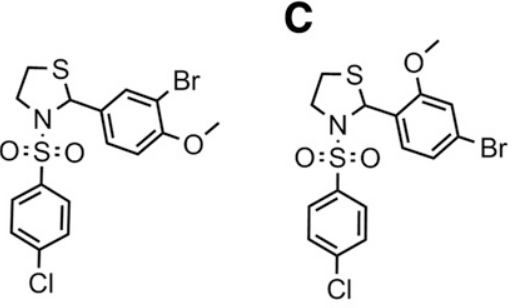

Fig. 1. Structure of (A) BMS-986187, (B) BMS-986122, and (C) BMS986124.

family (for review, see Katritch et al., 2014). $\mathrm{Na}^{+}$binds at a well described site within the 7-TM bundle and contributes to stabilization of the receptor in an inactive state with reduced affinity for agonists (Pert et al., 1973; Pert and Snyder, 1974; Liu et al., 2012). We previously hypothesized (Livingston and Traynor, 2014) that allosteric disruption of $\mathrm{Na}^{+}$binding may be a common mechanism for PAMs of class A GPCRs.

Although BMS-986187 possesses selectivity for $\delta$-OR over $\mu$-OR, it does appear to have some PAM activity at $\mu$-OR when endomorphin 1 is used as the orthosteric ligand (Burford et al., 2015). This and the structural and functional similarities between the $\mu$-OR and $\delta$-OR led us to examine the action of BMS-986187 at $\mu$-OR and to test the hypothesis of a general mechanism of action of allosteric modulation of GPCRs by studying whether the binding of the $\delta$-OR-PAM BMS-986187 and $\mathrm{Na}^{+}$ions are mutually incompatible at both $\delta$-OR and $\mu$-OR. Finally, we asked whether the allosteric sites on the two receptors are similar by using the silent allosteric modulator BMS-986124, which acts as an antagonist at the allosteric site in $\mu$-OR (Burford et al., 2013). We also investigated whether these modulators have activity at the closely related $\kappa$-opioid receptor $(\kappa-\mathrm{OR})$ and nociception receptor (NOPR).

Overall, our findings confirm that the selective $\delta$-PAM BMS986187 has PAM activity at $\mu$-OR, and we further show that this compound is also a PAM at $\kappa$-OR but not at NOPR. In addition, we have found that the $\mu$-PAM BMS-986122 is a silent allosteric modulator at $\delta$-OR and $\kappa$-OR. Together, these data suggest that the allosteric binding sites on $\mu$-OR, $\delta$-OR, and $\kappa$-OR may be conserved. The results have ramifications for the identification of the allosteric site(s) and for drug development of allosteric modulators for the opioid receptors.

\section{Materials and Methods}

Materials. $\left[{ }^{3} \mathrm{H}\right]$-Diprenorphine (DPN) and GTP $\gamma^{35} \mathrm{~S}$ [(guanosine5'-O(3-thio)triphosphate] were from PerkinElmer Life Sciences (Cambridge, MA). All tissue culture medium, penicillin-streptomycin, geneticin (G148), trypsin, and fetal bovine serum (FBS) were from Invitrogen (Carlsbad, CA). DAMGO, naloxone, and morphine sulfate were from Sigma-Aldrich (St. Louis, MO). PathHunter detection reagents were from DiscoveRx (Freemont, CA). Lance-Ultra cAMP detection reagents were from PerkinElmer Life Sciences. BMS986122, BMS-986124, and BMS-986187 (structures in Fig. 1) were synthesized or obtained as previously described (Burford et al., 2013, 2015). Other drugs were from the Opioid Basic Research Center at the University of Michigan. All other chemicals, unless otherwise specified, were purchased from Sigma.

Cell Lines and Membrane Preparation. The generation and maintenance of 66 rat glioma cells stably transfected with rat $\mu$-opioid receptor $(\mu$-OR) or rat $\delta$-opioid receptor $(\delta$-OR) were performed as described (Clark et al., 2008). Chinese hamster ovary (CHO) cells expressing human $\kappa$-OR, human embryonic kidney (HEK) 293T cells expressing human ORL1, and Flp-In CHO expressing human $\delta$-OR $(\mathrm{CHO}-\delta$ ) were generated and maintained Dulbecco's modified Eagle's medium with $10 \%$ FBS in the presence of $0.4 \mathrm{mg} / \mathrm{ml}$ of Geneticin and $0.1 \%$ penicillin/streptomycin. Cell membranes were prepared for binding assays as described (Livingston and Traynor, 2014). Briefly, cells were grown to confluence and washed twice with $37^{\circ} \mathrm{C}$ phosphatebuffered saline ( $\mathrm{pH}$ 7.4). Cells were detached in harvesting buffer (20 mM HEPES, $150 \mathrm{mM} \mathrm{NaCl}, 0.68 \mathrm{mM}$ EDTA, pH 7.4) and pelleted by centrifugation at $200 \mathrm{~g}$ for 3 minutes at room temperature. The pellet was resuspended in ice-cold $50 \mathrm{mM}$ Tris ( $\mathrm{pH}$ 7.4) and homogenized using a Tissue Tearor (Dremel, Mount Prospect, IL). This homogenate was centrifuged at $20,000 \mathrm{~g}$ at $4^{\circ} \mathrm{C}$ for 20 minutes. The pellet was then resuspended, homogenized, and centrifuged once more. The final pellet was resuspended in $50 \mathrm{mM}$ Tris ( $\mathrm{pH}$ 7.4) using a glass Dounce homogenizer, and aliquots were flash-frozen in liquid nitrogen. Aliquots were stored at $-80^{\circ} \mathrm{C}$ until use. Protein concentration was determined using the bicinchoninic acid quantification method with bovine serum albumin as the standard.

CHO PathHunter cells expressing enzyme acceptor (EA)-tagged $\beta$-arrestin-2 and ProLink (PK)-tagged $\mu$-OR receptor $(\mathrm{CHO}-\mu)$ were from DiscoveRx. Cells were grown in F-12 media (11765; Invitrogen) containing Hyclone FBS 10\%, Hygromycin $300 \mu \mathrm{g} / \mathrm{ml}$, Geneticin (G418) $800 \mu \mathrm{g} / \mathrm{ml}$ and maintained at $37^{\circ} \mathrm{C}$ in a humidified incubator containing $5 \% \mathrm{CO}_{2}$. These cells were used for $\beta$-arrestin- 2 recruitment assays and inhibition of forskolin-stimulated cAMP accumulation assays described as follows.

Radioligand Binding Assays. Ligand binding assays were performed using the cell membrane homogenates described in the preceding section. Competition binding assays were performed as previously described (Clark et al., 2003). Briefly, ${ }^{3} \mathrm{H}-\mathrm{DPN}(0.2-0.3 \mathrm{nM})$ was incubated in assay buffer (50 mM Tris, $\mathrm{pH} 7.4,100 \mathrm{mM} \mathrm{NaCl}$, $5 \mathrm{mM} \mathrm{MgCl}_{2}, 1 \mathrm{mM}$ EDTA, $10 \mu \mathrm{M}$ GTP $\gamma \mathrm{S}$ ) with $10 \mu \mathrm{g}$ of membrane protein, orthosteric ligand, and allosteric ligand (or vehicle) to promote a low-affinity state of the receptor. In some experiments, the $\kappa$-OR ligand ${ }^{3} \mathrm{H}-\mathrm{U} 69,593$ was examined in Tris-HCl buffer $(\mathrm{pH} 7.4)$ only. Nonspecific binding was determined in the presence of $10 \mu \mathrm{M}$ naloxone. Assays were incubated at room temperature for 7590 minutes to reach equilibrium and then terminated and counted as described (Livingston and Traynor, 2014). Three independent experiments, each done in duplicate, were performed, and the values were pooled to generate the mean curves as displayed in the figures.

GTP $\gamma^{35} \mathbf{S}$ Assays. GTP $\gamma^{35} \mathrm{~S}$ binding experiments were performed as described (Traynor and Nahorski, 1995) using cell-membrane homogenates prepared as described. Briefly, 10- $\mu \mathrm{g}$ aliquots of membrane protein were incubated for 1 hour at $25^{\circ} \mathrm{C}$ in buffer $(50 \mathrm{mM}$ Tris, $\mathrm{pH} 7.4,100 \mathrm{mM} \mathrm{NaCl}, 5 \mathrm{mM} \mathrm{MgCl}{ }_{2}, 1 \mathrm{mM}$ EDTA) with $0.1 \mathrm{nM}$ GTP $\gamma^{35} \mathrm{~S} 30 \mu \mathrm{M}$ GDP, orthosteric ligand, and allosteric ligand (or vehicle). An internal standard at $10 \mu \mathrm{M}$ (DAMGO [([D-Ala ${ }^{2}$, $\mathrm{N}-\mathrm{MePhe}^{4}$, Gly-ol]-enkephalin)] for $\mu$-OR, SNC80 for $\delta$-OR, U69,593 for $\kappa$-OR, and nociceptin for NOPR) was used to define maximal activation, water, or vehicle-defined basal binding. The assays were terminated and counted as described (Livingston and Traynor, 2014). Three independent experiments, each done in duplicate, were performed, and the values were pooled to generate mean curves as displayed in the figures.

PathHunter $\boldsymbol{\beta}$-Arrestin-2 Assay. Confluent flasks of $\mathrm{CHO}-\mu$ cells were harvested with TrypLE Express and resuspended in F-12 media supplemented with $10 \%$ FBS and $25 \mathrm{mM}$ HEPES at a density of $6.67 \times 10^{5}$ cells $/ \mathrm{ml}$ and plated ( $\left.3 \mu \mathrm{l} / \mathrm{well}\right)$ into white solid TC-treated 1536-well plates (Corning Inc., Corning, NY). Plates were incubated overnight at $37^{\circ} \mathrm{C}$ in a $5 \% \mathrm{CO}_{2}$ humidified incubator. The next day, increasing concentrations of BMS-986187 $(40 \mathrm{nl}$ of $100 \times$ final concentration in $100 \%$ dimethylsulfoxide) were added to separate rows of the assay plates by acoustic dispense using an Echo-550 (Labcyte, Sunnyvale, CA) from Echo-qualified 1536-well source plates (Labcyte). Next, $1 \mu$ l of increasing concentrations of DAMGO $(4 \times$ final concentration in assay buffer) were added to separate columns of the 
assay plates containing cells. Plates were covered with a lid and incubated at room temperature for 90 minutes. Incubations were terminated by the addition of $2 \mu \mathrm{l}$ of PathHunter Reagent (DiscoveRx, Fremont, CA). Luminescence was measured 1 hour later using a Viewlux imaging plate reader (PerkinElmer).

Inhibition of Forskolin-Stimulated cAMP Accumulation Assays. CHO- $\mu$ cells were grown to confluence, harvested, and resuspended at $10^{6}$ cells $/ \mathrm{ml}$ in assay buffer (Hanks' balanced salt solution $+25 \mathrm{mM}$ HEPES, $+0.05 \%$ bovine serum albumin). Increasing concentrations of BMS-986187 ( $30 \mathrm{nl}$ of $100 \times$ final concentration in $100 \%$ dimethylsulfoxide) were added to separate rows of 1536-well white solid NT plates by acoustic dispense using an Echo550 (Labcyte). Next, $1 \mu \mathrm{l}$ of increasing concentrations of DAMGO (at $3 \times$ final concentration in assay buffer) was added to separate columns of the plates. Then, $1 \mu \mathrm{l}$ of cells ( 1000 cells/well) was added to all wells, followed by $1 \mu \mathrm{l}$ of forskolin ( $3 \times$ final concentration in assay buffer). Plates were lidded and incubated for 45 minutes at room temperature. Incubations were terminated by the addition of Lance-Ultra cAMP detection reagent (PerkinElmer) (1.5 $\mu$ l of Eu-cryptate-labeled cAMP tracer in lysis buffer, followed by $1.5 \mu \mathrm{l}$ of U-light conjugated anticAMP antibody in lysis buffer). After a 1-hour incubation at room temperature, time-resolved fluorescence was detected on a Viewlux or Envision plate reader (PerkinElmer) with excitation at $337 \mathrm{~nm}$ and emission reads at 615 and $665 \mathrm{~nm}$. The ratiometric data $(665 \mathrm{~nm}$ $\mathrm{read} / 615 \mathrm{~nm}$ read) $\times 10,000$ were then converted to cAMP (nanomolar) based on a standard curve for cAMP run at the same time under identical conditions.

Data Analysis and Reporting. Data were analyzed using GraphPad Prism version 6.01 (GraphPad, San Diego, CA). Orthosteric ligand affinity $\left(K_{\mathrm{i}}\right)$ values and potency $\left(\mathrm{EC}_{50}\right)$ values were determined using nonlinear regression, with basal and maximal values constrained and are presented as mean \pm S.E.M. or with $95 \%$ confidence limits. Functional cooperativity values $(\alpha \beta)$ and the affinities of allosteric modulators for the orthosteric agonist-unoccupied receptor $\left(\mathrm{K}_{\mathrm{B}}\right)$ were obtained using the allosteric ternary complex model (Christopoulos and Kenakin, 2002; Leach et al., 2007) or a derivation of the allosteric ternary complex model (Leach et al., 2010). Sample size was predetermined to be a minimum of three independent experiments. None of the functional assays was blinded to investigators, and no data were excluded.

\section{Results}

Activity of the $\delta$-PAM, BMS-986187, at $\mu$-OR. BMS986187 is reported to have a 100 -fold selectivity for $\delta$-OR compared with $\mu$-OR, although initial data on BMS-986187 suggested that the compound is an efficacious, yet low, affinity PAM at $\mu$-OR (Burford et al., 2015). To confirm the PAM activity of BMS-986187 at $\mu$-OR, we studied the effects of BMS-986187 using cell-membrane preparations from $\mathrm{C} 6$ rat glioma cells stably expressing rat $\mu \mathrm{OR}$ (C6 $\mu$, Lee et al., 1999). Since we have previously shown that modulators act by allosterically displacing $\mathrm{Na}^{+}$ions from inactive $\mu$-OR, binding was measured by competition assay using the orthosteric antagonist $\left[{ }^{3} \mathrm{H}\right]$-diprenorphine $\left(\left[{ }^{3} \mathrm{H}\right]-\mathrm{DPN}\right)$ in the presence of $\mathrm{Na}^{+}$ions and GTP $\gamma \mathrm{S}$ to uncouple heterotrimeric $\mathrm{G}$ protein and so stabilize inactive $(\mathrm{R})$ conformations of the receptor (Livingston and Traynor, 2014). We verified that BMS-986187 does not compete with $\left[{ }^{3} \mathrm{H}\right]$-DPN, (Fig. 2A) for the orthosteric site on $\mu$-OR or stimulate GTP $\gamma^{35} \mathrm{~S}$ binding (Fig. 2B). Conversely, BMS-986187 significantly increased the binding affinity $\left(K_{\mathrm{i}}\right)$ of agonists for $\mu$-OR, consistent with a positive allosteric ligand. As such, in the presence of $10 \mu \mathrm{M}$ BMS986187, the affinity of the $\mu$-OR agonist DAMGO was enhanced 11-fold from 724 to $63 \mathrm{nM}$, whereas the affinity of methadone was increased 24-fold, from 603 to $25 \mathrm{nM}$. In contrast, the affinity of morphine, a partial agonist, was enhanced by a nonsignificant 3-fold, from 229 to $71 \mathrm{nM}$ (Fig. 2; Table 1).

The allosteric modulatory actions of BMS-986187 at $\mu$-OR were then investigated in three signaling assays. BMS-986187 $(1 \mu \mathrm{M})$ significantly enhanced the potency of DAMGO by 6 -fold, from 91 to $16 \mathrm{nM}$; methadone by 20 -fold, from 203 to $10 \mathrm{nM}$, but it shifted morphine only a nonsignificant 3-fold, from 120 to $38 \mathrm{nM}$ in the GTP $\gamma^{35} \mathrm{~S}$ binding assay in membranes from $\mathrm{C} 6 \mu$ cells. There was also a significant increase in the maximal effect of the partial agonist morphine, from $70 \%$ to $90 \%$ of the DAMGO response (Fig. 2; Table 1). The larger shift seen with methadone allowed us to repeat the assay in the presence of increasing concentrations of BMS-986187 to generate a limited series of concentration-response curves (Fig. 3) that, when analyzed using a derivation of the allosteric ternary complex model (Leach et al., 2010; see Materials and Methods), resulted in a $\mathrm{pK}_{\mathrm{B}}$ value, representing the affinity of BMS-986187 for the unoccupied $\mu$-OR of $5.23 \pm 0.19$ and a $\log \alpha \beta$ value of $1.16 \pm 0.13$ for the cooperativity between methadone and BMS-986187.

We then used high throughput methods to generate a more comprehensive series of concentration-effect curves to study the action of the modulator on adenylate cyclase (AC) inhibition and $\beta$-arrestin- 2 recruitment, which enabled us to determine binding affinity and allosteric cooperativity using the full operational model of allostery (Leach et al., 2007; see Materials and Methods). Using the inhibition of AC in CHO- $\mu$ cells as a downstream measure of Gi/o signaling, the BMS986187 concentration dependently enhanced the potency of DAMGO by 10 -fold ( $\mathrm{EC}_{50}$ from 66 to $7 \mathrm{pM}$ ) (Fig. 4A). These data afforded a $\mathrm{pK}_{\mathrm{B}}$ value for BMS-986187 of $4.78 \pm 0.15$ and a $\log \alpha \beta$ value for cooperativity of $1.57 \pm 0.17$. Analysis using the simplified operational model (Leach et al., 2010) gave the same result $\left(\mathrm{pK}_{\mathrm{B}}=4.83 \pm 0.15 ; \log \alpha \beta=1.52 \pm 0.17\right)$. When recruitment of $\beta$-arrestin- 2 was measured as a signaling output in the same cells, BMS-986187 was also observed to concentration dependently enhance the potency of DAMGO $\left(\mathrm{EC}_{50}\right.$ from 170 to $\left.3 \mathrm{nM}\right)$, representing a 58-fold shift in DAMGO potency (Fig. 4B). Analyses of these data afforded a $\mathrm{pK}_{\mathrm{B}}$ value for BMS-986187 of $4.61 \pm 0.06$ (Fig. 4) and a $\log \alpha \beta$ value of cooperativity of $2.1 \pm 0.05$.

The coupling efficiency of the AC assay is much higher than in the $\beta$-arrestin- 2 or GTP $\gamma^{35} \mathrm{~S}$ assays as evidenced by the 2500 -fold higher potency of DAMGO in the former assay. Because of this high coupling efficiency, BMS-986187 alone inhibited adenylate cyclase (Fig. 4C). In comparison, no agonist activity was observed in the GTP $\gamma^{35} \mathrm{~S}$ assay (Fig. 2B) or the $\beta$-arrestin- 2 assay (Fig. 4D). This direct agonist activity in the AC assay at $\mu$-OR is not due to an action of BMS-986187 at the orthosteric site on $\mu$-OR, as shown by the ${ }^{3} \mathrm{H}$-DPN displacement assays (Fig. 2A), and so the compound should be designated an "ago-PAM" (Christopoulos et al., 2014), reminiscent of its activity at the $\delta$-OR, where it is capable of G-protein activation, AC inhibition, and mitogen-activated protein kinase activation in the absence of orthosteric agonist, in addition to allosterically enhancing orthosteric agonist affinity and activity (Burford et al., 2015). The ago-PAM efficacy of BMS-986187 at $\mu$-OR is low, such that this can only be observed when measured using the more amplified AC signaling output in cells overexpressing $\mu$-OR receptors.

BMS-986187 Acts to Disrupt $\mathrm{Na}^{+}$Binding at Both $\boldsymbol{\mu}$-OR and $\boldsymbol{\delta}$-OR. $\mathrm{Na}^{+}$ion binding is highly coordinated and contributes to the stabilization of inactive receptor $(R ;$ Fenalti 

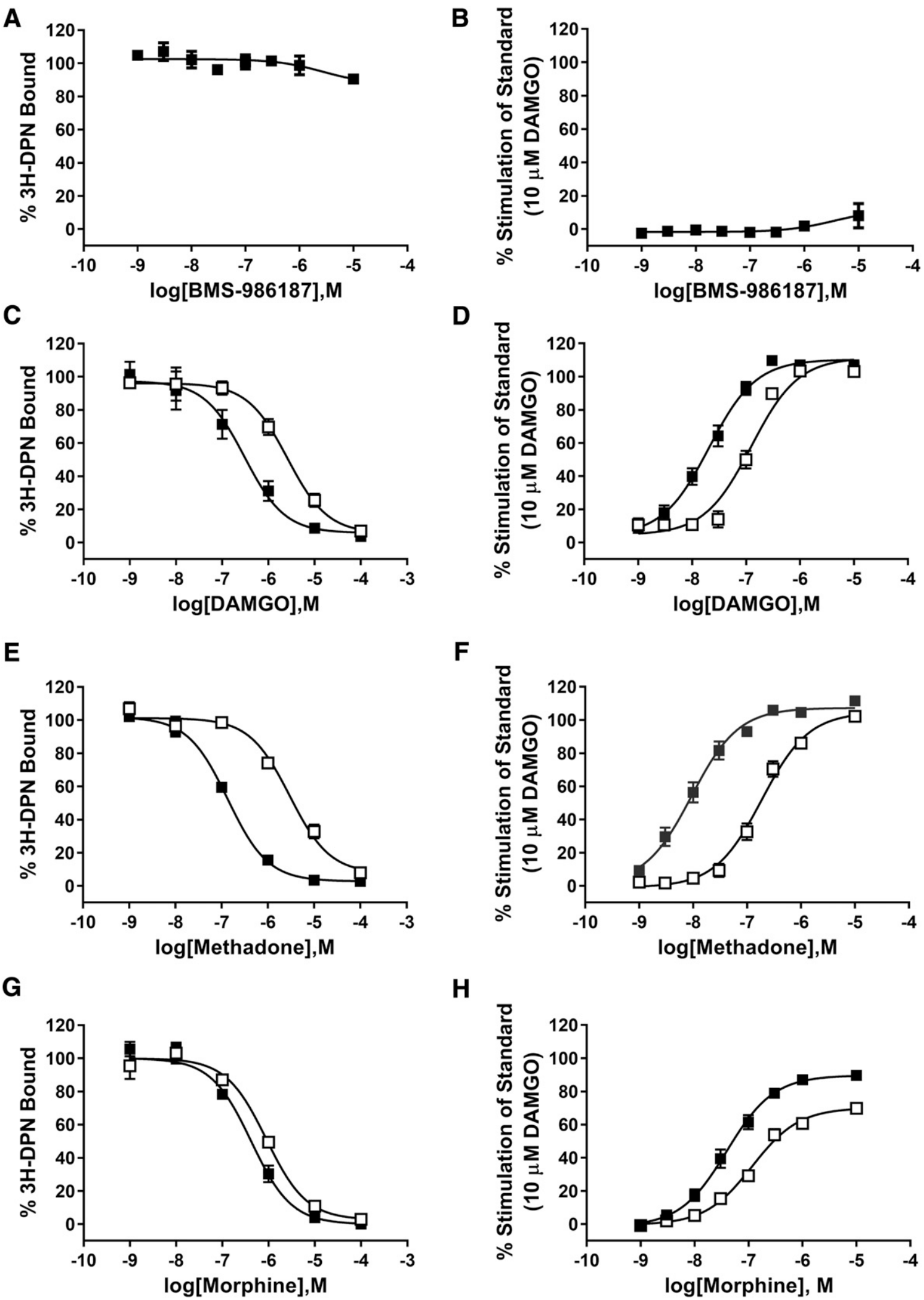

H

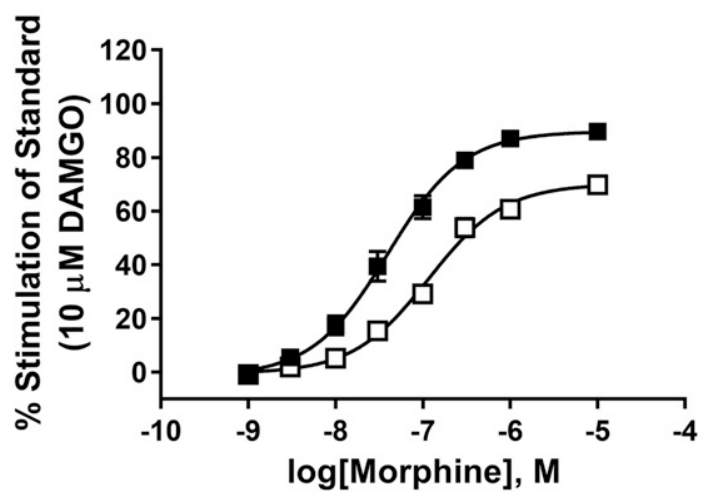

Fig. 2. BMS-986187 enhances the affinity, potency, and/or maximal stimulation of several opioid ligands at $\mu$-OR expressed in C6 cell membranes. (A) BMS-986187 alone did not displace ${ }^{3} \mathrm{H}$-DPN from the orthosteric site or (B) stimulate GTP $\gamma^{35} \mathrm{~S}$ binding. The presence of $10 \mu \mathrm{M}$ BMS-986187 (filled symbols) increased the binding affinity and potency or maximal effect to stimulate GTP $\gamma^{35} \mathrm{~S}$ for DAMGO (C and D), methadone (E and F), and morphine ( $\mathrm{G}$ and $\mathrm{H}$ ) compared with control conditions (open symbols). Data are presented as percent ${ }^{3} \mathrm{H}-\mathrm{DPN}$ bound for the binding data or percentage of stimulation of a maximal concentration $(10 \mu \mathrm{M})$ of the full-agonist DAMGO for the GTP $\gamma^{35} \mathrm{~S}$ data. Nonlinear regression analysis using GraphPad Prism 6.01 fit all curves to one site. Data shown are means \pm S.E.M. of three $\left({ }^{3} \mathrm{H}-\mathrm{DPN}\right)$ or four $\left(\mathrm{GTP} \gamma^{35} \mathrm{~S}\right)$ independent experiments each performed in duplicate. 
TABLE 1

Effects of BMS-986187 on ligand affinity and $\left[{ }^{35} \mathrm{~S}\right] \mathrm{GTP} \gamma \mathrm{S}$ binding at $\mu, \delta, \kappa$, and NOP receptors

\begin{tabular}{|c|c|c|c|c|c|c|}
\hline & \multicolumn{2}{|c|}{$\mathrm{Ki}(\mathrm{nM})$} & \multicolumn{2}{|c|}{ Potency $\left(\mathrm{GTP} \gamma^{35} \mathrm{~S}\right)(\mathrm{nM})$} & \multicolumn{2}{|c|}{$\operatorname{Emax}\left(\mathrm{GTP} \gamma^{35} \mathrm{~S}\right)(\%$ Standard } \\
\hline & Control & BMS-986187 & Control & BMS-986187 & Control & BMS-986187 \\
\hline \multicolumn{7}{|l|}{$\mu-\mathrm{OR}_{a}$} \\
\hline DAMGO & $\begin{array}{c}724 \\
(562-912)\end{array}$ & $\begin{array}{c}63 \\
(13-316)^{f}\end{array}$ & $\begin{array}{c}91 \\
(55-154)\end{array}$ & $\begin{array}{c}16 \\
(6-38)^{f}\end{array}$ & $\begin{array}{c}111 \\
(103-119)\end{array}$ & $\begin{array}{c}110 \\
(105-115)\end{array}$ \\
\hline Methadone & $\begin{array}{c}603 \\
(288-1259)\end{array}$ & $\begin{array}{c}25 \\
(19-32)^{f}\end{array}$ & $\begin{array}{c}203 \\
(121-284)\end{array}$ & $\begin{array}{c}10 \\
(3-24)^{f}\end{array}$ & $\begin{array}{c}105 \\
(98-111)\end{array}$ & $\begin{array}{c}107 \\
(102-111)\end{array}$ \\
\hline Morphine & $\begin{array}{c}229 \\
(178-302)\end{array}$ & $\begin{array}{c}71 \\
(43-120)^{f}\end{array}$ & $\begin{array}{c}120 \\
(85-166)\end{array}$ & $\begin{array}{c}38 \\
(10-151)\end{array}$ & $\begin{array}{c}70 \\
(67-74)\end{array}$ & $\begin{array}{c}90 \\
(83-97)^{f}\end{array}$ \\
\hline \multicolumn{7}{|l|}{$\delta-\mathrm{OR}^{b}$} \\
\hline $\begin{array}{l}\text { Leu- } \\
\text { enkephalin }\end{array}$ & $\begin{array}{c}221 \\
(119-324)\end{array}$ & $\begin{array}{c}7 \\
(3-12)^{f}\end{array}$ & $\begin{array}{c}28 \\
(18-42)\end{array}$ & $\begin{array}{c}3.6 \\
(1.6-8.2)^{f}\end{array}$ & $\begin{array}{c}87 \\
(79-95)\end{array}$ & $\begin{array}{c}94 \\
(89-100)\end{array}$ \\
\hline SNC80 & $\begin{array}{c}71 \\
(20-122)\end{array}$ & $\begin{array}{c}5 \\
(3-7)^{f}\end{array}$ & NT & $\mathrm{NT}$ & NT & NT \\
\hline TAN67 & $\begin{array}{c}10 \\
(7-14)\end{array}$ & $\begin{array}{c}3 \\
(0.2-5.8)^{f}\end{array}$ & NT & NT & NT & NT \\
\hline \multicolumn{7}{|l|}{$\kappa-\mathrm{OR}^{c}$} \\
\hline $\mathrm{U} 69,593^{d}$ & $\begin{array}{c}0.9 \\
(0.3-1.6)\end{array}$ & $\begin{array}{c}0.3 \\
(0.2-0.5)^{g}\end{array}$ & $\begin{array}{c}881 \\
(480-1601)\end{array}$ & $\begin{array}{c}64 \\
(35-121)^{f}\end{array}$ & $\begin{array}{c}105 \\
(82-128)\end{array}$ & $\begin{array}{c}104 \\
(89-118)\end{array}$ \\
\hline Dynorphin A & NT & NT & $\begin{array}{c}15 \\
(11-19)\end{array}$ & $\begin{array}{c}1.0 \\
(0.5-2)^{f}\end{array}$ & $\begin{array}{c}100 \\
(95-105)\end{array}$ & $\begin{array}{c}95 \\
(86-104)\end{array}$ \\
\hline Salvinorin A & NT & NT & $\begin{array}{c}322 \\
(221-471)\end{array}$ & $\begin{array}{c}25.9 \\
(11-60)^{f}\end{array}$ & $\begin{array}{c}110 \\
(97-122)\end{array}$ & $\begin{array}{c}116 \\
(101-131)\end{array}$ \\
\hline Diprenorphine & NT & NT & $\begin{array}{c}46 \\
(25-37)\end{array}$ & $\begin{array}{c}8.9 \\
(1.9-26)\end{array}$ & $\begin{array}{c}31 \\
(25-37)\end{array}$ & $\begin{array}{c}56 \\
(47-67)^{f}\end{array}$ \\
\hline \multicolumn{7}{|l|}{$\mathrm{NOPR}^{e}$} \\
\hline Nociceptin & NT & NT & $\begin{array}{c}2.6 \\
(2.0-4)\end{array}$ & $\begin{array}{c}2.1 \\
(1.5-3)\end{array}$ & $\begin{array}{c}102 \\
(94-110)\end{array}$ & $\begin{array}{c}105 \\
(100-111)\end{array}$ \\
\hline Ro-64-6198 & NT & NT & $\begin{array}{c}13 \\
(8.0-19) \\
\end{array}$ & $\begin{array}{c}18 \\
(7.8-45) \\
\end{array}$ & $\begin{array}{c}109 \\
(102-115)\end{array}$ & $\begin{array}{c}108 \\
(93-123) \\
\end{array}$ \\
\hline
\end{tabular}

NT, not tested. Values in parentheses represent $95 \%$ confidence intervals.

${ }^{a}$ In $\mathrm{C} 6$ rat glioma cells expressing rat $\mu$-OR.

${ }^{b}$ Data taken from Burford et al. (2015).

${ }^{c}$ In $\mathrm{CHO}$ cells expressing human $\kappa$-OR.

${ }^{d} \mathrm{Ki}$ values determined by saturation binding in Tris-buffer.

${ }^{e}$ HEK293 cells expressing human NOPR.

${ }^{f}$ Significantly different from control conditions (nonoverlapping confidence intervals).

${ }^{g} P=0.03$ compared with control (paired $t$ test)

et al., 2014; Katritch et al., 2014). Disruption of $\mathrm{Na}^{+}$coordination leads to an increased level of active-state $\mu$-OR $\left(\mathrm{R}^{*}\right)$ and therefore an increase in the binding affinity of orthosteric agonists (Pert et al., 1973; Pert and Snyder, 1974). We have previously demonstrated that the binding of the $\mu$-PAM, BMS986122, and $\mathrm{Na}^{+}$ions are incompatible leading BMS-986122 to promote $\mathrm{R}^{*}$ (Livingston and Traynor, 2014). Here we show that the potency $\left(\mathrm{EC}_{50}\right)$ of $\mathrm{Na}^{+}$ions to inhibit the binding of the $\mu$-OR agonist DAMGO to membranes from $\mathrm{C} 6 \mu$ cells is reduced by 5 -fold in the presence of BMS-986187 [from 3.8 (0.6-20) to $20.2(12-34) \mathrm{mM}$ ] (Fig. 5A), although because of a small window in the control group, the effect did not reach significance. Likewise, at the $\delta$-OR expressed in $\mathrm{CHO}$ cells, there was a negative relationship between $\mathrm{Na}^{+}$ions and BMS-986187 such that BMS-986187 caused a concentrationdependent 4-fold rightward shift in the $\mathrm{NaCl}$ concentrationresponse curve [from $45(35-59)$ to $172(100-300) \mathrm{mM}$ ] to inhibit the constitutive receptor-mediated GTP ${ }^{35} \mathrm{~S}$ binding that occurs in $\mathrm{Na}^{+}$-free buffer (Szekeres and Traynor, 1997) (Fig. 5B).

BMS-986122 and BMS-986187 are Competitive at $\boldsymbol{\mu}$-OR and $\boldsymbol{\delta}$-OR. Although our initial hypothesis predicted that BMS-986122 and BMS-986187 have distinct binding sites on $\mu$-OR based on their diverse structural features (Fig. 1), the fact that they show a similar pattern of probe dependence in their interaction with full versus partial agonists versus antagonists and a similar interaction with $\mathrm{Na}^{+}$ions could indicate that they engage $\mu \mathrm{OR}$ at the same allosteric site(s). To

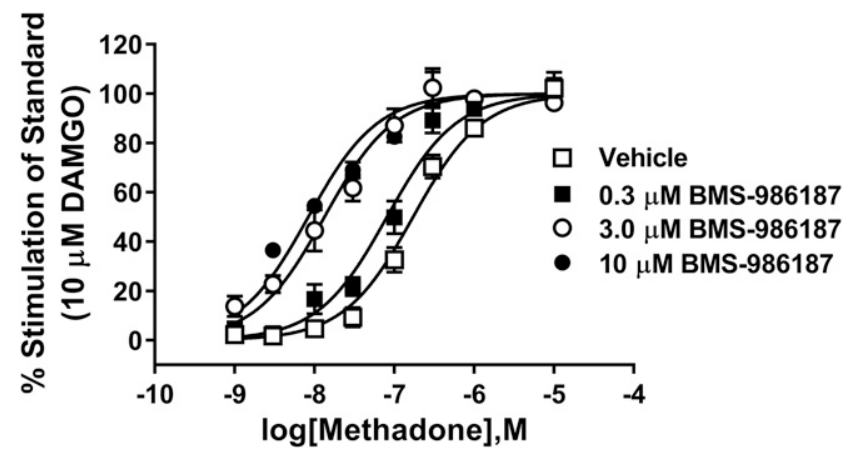

Fig. 3. BMS-986187 has a concentration-dependent effect on the potency of methadone to activate G protein. Stimulation of GTP $\gamma^{35} \mathrm{~S}$ binding in C6 $\mu$ cell membranes by methadone was performed in the presence of increasing concentrations $(0.3-10 \mu \mathrm{M})$ of BMS-986187. Data were analyzed using a modified allosteric ternary complex model as described in Materials and Methods. Points shown are means \pm S.E.M. of three independent experiments, each in duplicate. 

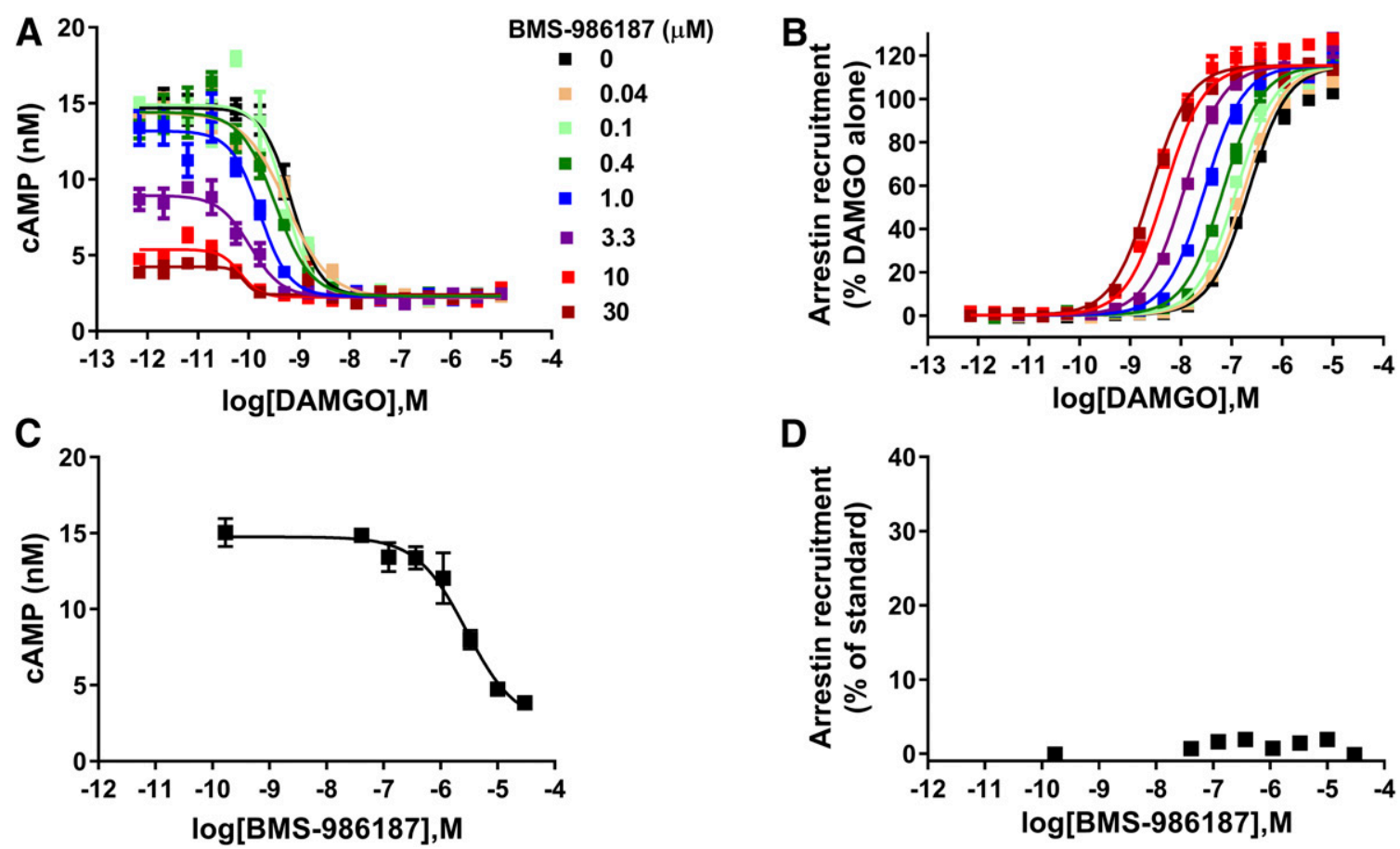

Fig. 4. Effects of BMS-986187 on opioid-mediated adenylate cyclase (AC) inhibition and $\beta$-arrestin-2 recruitment in CHO- $\mu$ cells. (A) Concentrationresponse curves for the full $\mu$-OR agonist DAMGO to inhibit AC in the absence or presence of increasing concentrations of BMS-986187. (B) Concentration-response curves of DAMGO to recruit $\beta$-arrestin- 2 were performed in the absence or presence of increasing concentrations of BMS-986187 as listed in (A). (C and D) Effect of BMS-986187 on inhibition of AC or recruitment of $\beta$-arrestin- 2 in the absence of orthosteric agonist. Data were analyzed using GraphPad Prism 6.01, and points shown are means \pm S.E.M. of three independent experiments, each done in quadruplicate. Data in (A and B) were analyzed using an allosteric ternary complex model as described in Materials and Methods.

evaluate this possibility, we used the $\mu$-silent allosteric modulator ( $\mu$-SAM) BMS-986124, a close analog of BMS-986122 (Fig. 1), which has been previously reported to block BMS-986122 action at $\mu$-OR but having no effects alone (Burford et al., 2013). We asked whether BMS-986124 could inhibit the action of BMS-986187 at $\mu$-OR and even at $\delta$-OR.

BMS-986187, at $10 \mu \mathrm{M}$, produced a 6-fold increase in the potency of DAMGO to stimulate GTP $\gamma^{35} \mathrm{~S}$ binding in $\mathrm{C} 6 \mu$ cell membranes (from 91 to $16 \mathrm{nM}$ ) (Table 1). The addition of the $\mu$-SAM increased the $\mathrm{EC}_{50}$ of DAMGO [to $59.4(47.5-74.2) \mathrm{nM}$ ] such that the PAM effects of BMS-986187 were no longer significant (Fig. 6A). Using the same assay in membranes from C6 $\delta$ cells BMS-986187 (300 nM) displayed no agonism alone, but it enhanced the potency of the orthosteric agonist leu-enkephalin to stimulate $\mathrm{GTP} \gamma^{35} \mathrm{~S}$ by 6 -fold [from $378(287-498)$ to $65.4(44.9-95.4) \mathrm{nM}]$. This effect was reversed in the presence of BMS-986124 [217 (154-295) nM] (Fig. 6B). Furthermore, since BMS-986124 blocks the action of BMS-986122 at $\mu$-OR and BMS-986187 at $\delta$-OR, we predicted BMS-986122, because of its structural similarity to BMS986124 (Fig. 1), might bind to $\delta$-OR but lacks allosteric efficacy. In a separate set of experiments in C6 $\delta$ cell membranes, the presence of BMS-986187 (300 nM) increased the potency of Leu-enkephalin [from 715 (548-933) to 57.7 (42.1-79.0) $\mathrm{nM}$ ], but this increase was decreased by the addition of $30 \mu \mathrm{M}$ BMS-986122 [to $176(136-228) \mathrm{nM}$ ] (Fig. 6C). The fact that we observed only partial reversal may be explained by the finding that BMS-986122 might not be entirely silent at $\delta$-OR. For example, in a separate experiment, the compound slightly enhanced the potency of Leu-enkephalin [from $667(525-848)$ to $293(234-374) \mathrm{nM}$ ]
(Fig. 6D). BMS-986187 is an ago-PAM at $\delta$-OR and alone will stimulate GTP $\gamma^{35} \mathrm{~S}$ binding via the allosteric site. Both the $\mu$-SAM (BMS-986124) and the $\mu$-PAM (BMS986122) were able to inhibit the ago-PAM activity of BMS-986187 (Fig. 6E).

BMS-986187 Is a Positive Allosteric Modulator of $\boldsymbol{\kappa}$-OR. Since BMS-986187 has activity at both $\mu$-OR and $\delta$-OR, we sought to determine whether it also has activity at the $\kappa$-opioid receptor $(\kappa$-OR) since these three receptors share a high degree of homology as well as endogenous ligands. In CHO cells expressing the human $\kappa$-OR, GTP $\gamma^{35} \mathrm{~S}$ binding stimulated by the $\kappa$-OR-preferring peptide dynorphin $\mathrm{A}(1-17)$ was enhanced 15 -fold (from 15 to $1.0 \mathrm{nM}$ ) in the presence of $10 \mu \mathrm{M}$ BMS-986187 with no change in the maximal response (Fig. 7; Table 1). Similarly, the activities of the $\kappa$-OR agonist U69,593, the nonbasic nitrogen-containing agonist salvinorin A, and the partial agonist DPN (Traynor et al., 1987) were enhanced in the presence of $10 \mu \mathrm{M}$ BMS-986187. The potency of U69,593 was shifted 14-fold, from 881 to $64 \mathrm{nM}$, and the potency of salvinorin A was shifted by 12 -fold, from 322 to $26 \mathrm{nM}$, whereas the maximal responses to both compounds was unaltered (Fig. 7; Table 1). In contrast, the potency of the partial agonist DPN was not significantly shifted (46-8.9 nM), but the maximal stimulation was enhanced from $31 \%$ to $56 \%$ of that seen with U69,593 (Fig. 7; Table 1). Analysis of the concentration-response curves for the stimulation of GTP $\gamma^{35} \mathrm{~S}$ binding by U69,593, in the presence of BMS-986187 (Fig. 7B) using the simplified operational model (Leach et al., 2010), afforded a $\mathrm{pK}_{\mathrm{B}}$ value for the modulator of $6.22 \pm 0.19$ and a log $\alpha \beta$ value of $1.11 \pm 0.13$.

We could not investigate the effect of BMS-986187 using binding assays with ${ }^{3} \mathrm{H}$-DPN as the tracer ligand at $\kappa$-OR 

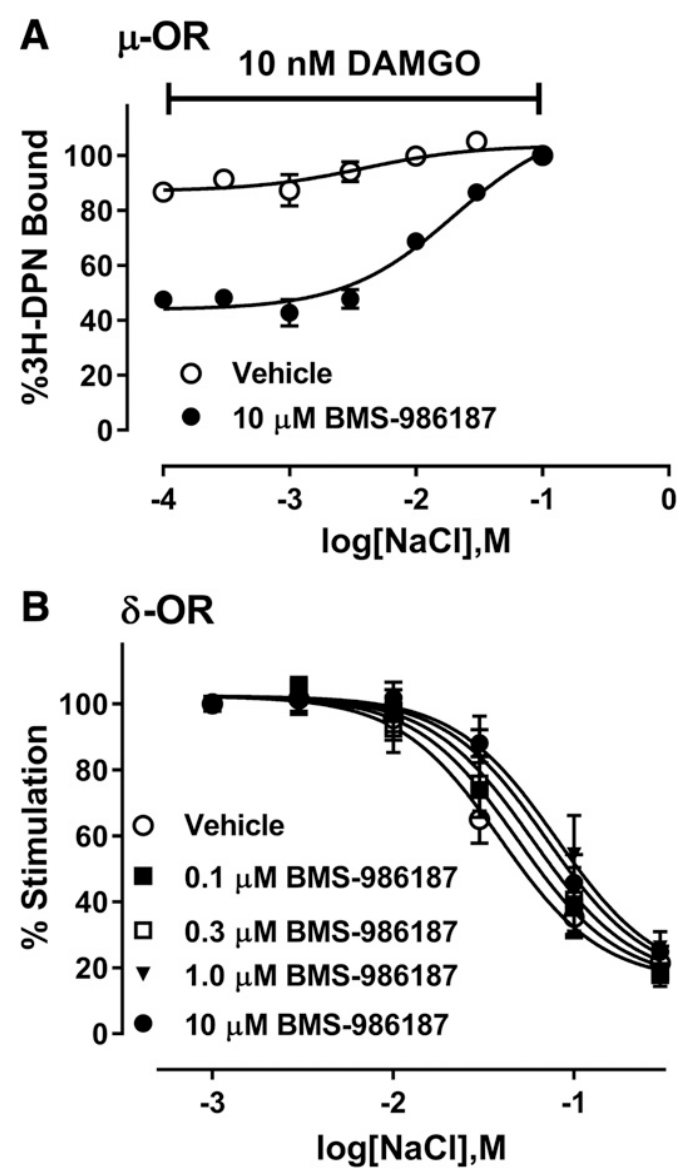

Fig. 5. Antagonism between $\mathrm{Na}^{+}$ions and BMS-986187. (A) The displacement by DAMGO of ${ }^{3} \mathrm{H}-\mathrm{DPN}$ binding to $\mu$-OR is inhibited by $\mathrm{Na}^{+}$ions (open circles). BMS-986187 $(10 \mu \mathrm{M})$ enhances the binding of DAMGO and reduces the potency of $\mathrm{Na}^{+}$ions to inhibit DAMGO binding (closed circles). (B) The ability of increasing concentrations of $\mathrm{NaCl}$ to decrease constitutive $\delta$-OR-mediated GTP ${ }^{35} \mathrm{~S}$ binding in the absence (open circles) or presence of increasing concentrations of BMS-986187 was measured in membranes from CHO- $\delta$ cells. Data were analyzed using GraphPad Prism 6.01 , and points shown are means \pm S.E.M. of three independent experiments, each in duplicate.

because DPN has agonist activity at this receptor and this action is sensitive to BMS-986187 (Fig. 7D). Consequently, we studied the effects of the modulators on the binding of ${ }^{3} \mathrm{H}-\mathrm{U} 69,593$. This was examined in Tris-buffers in the absence of added $\mathrm{Na}^{+}$ions and GTP. Even so, BMS-986187 enhanced the affinity of ${ }^{3} \mathrm{H}-\mathrm{U} 69,593$ to $\kappa$-OR from $K_{\mathrm{D}}=0.9 \pm 0.2$ to $0.3 \pm$ $0.1 \mathrm{nM}(P=0.03$; Fig. $7 \mathrm{E}$; Table 1$)$ without a change in the $B_{\text {max }}$. The effect is small because receptors will exist mostly in the $\mathrm{R}^{*}$ state under these conditions. Neither BMS-986122 nor BMS-986124 affected ${ }^{3} \mathrm{H}-\mathrm{U} 69,593$ binding alone, but BMS986124 prevented the BMS-986187-mediated enhancement of binding (Fig. $7 \mathrm{~F}$ ), suggesting that it is also a $\kappa$-SAM.

BMS-986122 and BMS-986187 Have no Detectable PAM Activity at NOPR. The nociceptin receptor (NOPR) is now recognized as a fourth member of the opioid receptor family (Cox et al., 2015) and, like the other family members, is coupled to $\mathrm{G} \alpha_{\mathrm{i} / \mathrm{o}}$ proteins. Using HEK293T cells expressing NOPR, concentration-response curves of the abilities of the endogenous ligand nociceptin and the small-molecule synthetic agonist R064-6198 to stimulate GTP $\gamma^{35} \mathrm{~S}$ binding were determined in the presence or absence of BMS-986187 (Fig. 8;
Table 1). Neither the potency nor maximal effect of either NOPR ligand was altered.

\section{Discussion}

Our results show that $\delta$-PAM BMS-986187 is also a $\mu$-PAM and $\kappa$-PAM, providing the first description of a $\kappa$-PAM. Moreover, the $\mu$-PAM BMS-986122 is a SAM, or allosteric antagonist, at $\delta$-OR, and the $\mu$-SAM BMS-986124 is an allosteric antagonist at $\mu$-OR, $\delta$-OR, and $\kappa$-OR. In addition, the probe dependence of BMS-986187 at the $\mu$-OR and $\kappa$-OR is the same as seen with BMS-986122 at the $\mu$-OR (Livingston and Traynor, 2014) and BMS-986187 at the $\delta$-OR (Burford et al., 2015). In particular, an increase in ligand affinity and potency was seen for full agonists but an increase occurred in the maximal effect for the partial agonists, morphine at $\mu$-OR and diprenorphine at the $\kappa$-OR, with little change in their affinity or potency. Finally, the mechanism of action of the PAMs at $\mu$-OR and $\delta$-OR involves destabilization of the inactive $\mathrm{Na}^{+}$-bound receptor. Thus, it appears that the allosteric ligand binding site on the $\mu-, \delta$-, and $\kappa$-OR is similar enough to recognize the same ligands and interact with the orthosteric site but also sufficiently promiscuous to accommodate different chemical scaffolds as exemplified by BMS986122 and BMS-986187 (Fig. 1). The findings provide pharmacologic evidence for a possible conserved allosteric site across the three naloxone-sensitive members of the opioid receptor family.

The average affinity of BMS-986187 for orthosteric-agonistfree $\mu$-OR $\left(\mathrm{pK}_{\mathrm{B}}\right)$ determined from the $\mathrm{GTP} \gamma^{35} \mathrm{~S}, \beta$-arrestin-2 and $\mathrm{AC}$ assays is $4.75 \pm 0.07$. In contrast, the $\mathrm{pK}_{\mathrm{B}}$ at the $\kappa$-OR derived from GTP $\gamma^{35} \mathrm{~S}$ data in 6.22 , similar to the reported average $\mathrm{pK}_{\mathrm{B}}$ value for BMS-986187 at $\delta$-OR (i.e., 6.02) (Burford et al., 2015). Since the $\mathrm{pK}_{\mathrm{B}}$ for BMS-986187 is independent of the ligand occupying the orthosteric site, we can compare these values to show that BMS-986187 is approximately 20 - to 30 -fold selective for binding to $\delta$-OR and $\kappa$-OR over $\mu$-OR. The cooperativity factor $(\log \alpha \beta)$ between DAMGO and BMS-986187 at $\mu$-OR for the GTP $\gamma^{35} \mathrm{~S}$ and adenylate cyclase assays is 1.57 , whereas there is a greater cooperativity in the $\beta$-arrestin- 2 assay $(\log \alpha \beta=2.1)$. The cooperativity factor $(\log \alpha \beta)$ between U69,593 and BMS986187 at $\kappa$-OR derived from GTP $\gamma^{35} \mathrm{~S}$ assay data is 1.1. This compares with full agonists (Leu-enkephalin and SNC80, respectively) at the $\delta$-OR that afforded $\log \alpha \beta$ values of 1.18 and 1.33 in the $\beta$-arrestin- 2 assay, 1.67 and 1.0 in the $\left[{ }^{35} \mathrm{~S}\right]$ GTP $\gamma \mathrm{S}$ assay, and 2.8 and 2.1 in the AC assay (Burford et al., 2015). Although it is not possible to compare these values directly because of the different orthosteric ligands used, the similarity between $\log \alpha \beta$ values at $\mu$-OR, $\delta$-OR and $\kappa$-OR suggests that the preference of BMS-986187 for the $\delta$-OR and $\kappa$-OR is mainly due to its higher binding affinity. It is worthy of note that the cooperativity values at $\mu$-OR are greater for $\beta$-arrestin- 2 than AC, whereas the opposite is true at the $\delta$-OR.

Previously, a 100-fold preference was reported for the ability of BMS-986187 to act as a PAM at the $\delta$-OR compared with the $\mu$-OR. This selectivity was determined by comparing the potency ratios for the compounds as PAMs at the $\mu$-OR using endomorphin-1 and the $\delta$-OR using Leu-enkephalin (Burford et al., 2015), and this could vary depending on the probes used, a facet that is complicated by the many endogenous ligands for the opioid receptor family. On the other 

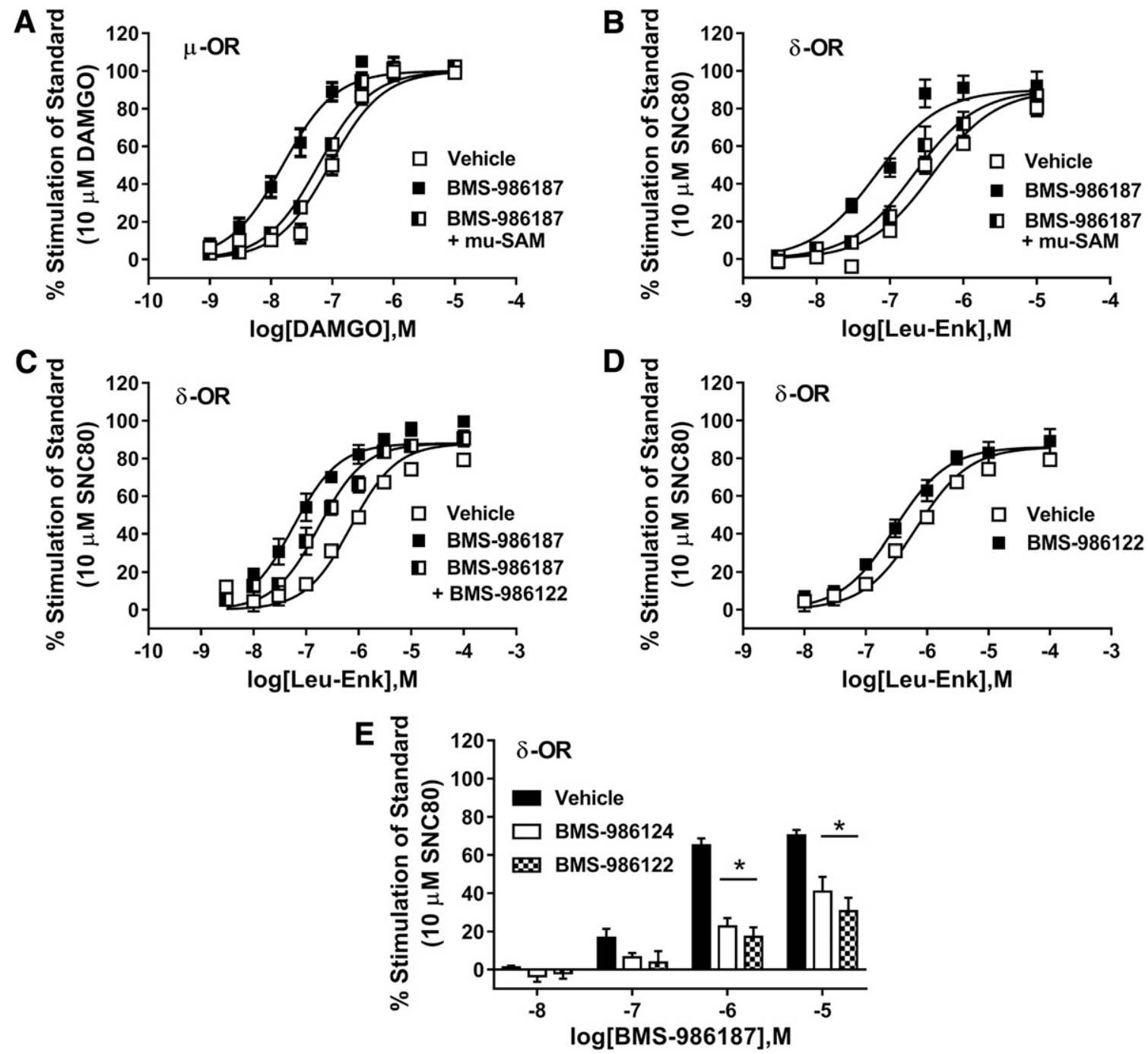

Fig. 6. Interactions between BMS-986187 and related allosteric modulators. (A) The ability of $10 \mu \mathrm{M}$ BMS-986187 to enhance the potency of DAMGOmediated GTP $\gamma^{35} \mathrm{~S}$ stimulation at the $\mu$-OR in C6 $\mu$ cell membranes was measured in the presence or absence of $30 \mu \mathrm{M}$ of the $\mu$-SAM BMS-986124. (B) In C6 $\delta$ cell membranes, the effect of $300 \mathrm{nM}$ BMS-986187 to enhance the potency of Leu-enkephalin-mediated GTP $\gamma^{35} \mathrm{~S}$ stimulation was measured in the presence or absence of the $\mu$-SAM $30 \mu \mathrm{M}$ BMS-986124. (C) The ability of $300 \mathrm{nM}$ BMS-986187 to enhance the potency of Leu-enkephalin-mediated GTP $\gamma^{35} \mathrm{~S}$ stimulation at $\delta$-OR was measured in the presence or absence of $30 \mu \mathrm{M}$ of the $\mu$-PAM BMS-986122. (D) $30 \mu \mathrm{M}$ BMS-986122 has a small effect on the potency of Leu-enkephalin to activate G protein. (E) BMS-986122 and BMS-986124 inhibit the ago-PAM action of BMS-986187 to stimulate GTP ${ }^{35} \mathrm{~S}$ binding to CHO $\delta$ cell membranes. *BMS-986187-mediated stimulation of GTP $\gamma^{35}$ S binding is different from the vehicle control and significantly inhibited by BMS-986122 or BMS-986122 ( analysis of variance with Tukey's post hoc test). Data shown are mean \pm S.E.M. from three experiments in duplicate. Potency values were obtained from fitting the data by linear regression with Hill slopes of unity using GraphPad Prism 6.01.

hand, the affinity values reported here are for the agonist unoccupied receptor and do not depend on the orthosteric ligand used; thus, the discrimination obtained is the actual selectivity for BMS-986187 between the $\mu$-OR and the $\kappa$ - or $\delta$-OR.

The apparent lack of selectivity of the allosteric modulator between $\kappa$ - and $\delta$-OR and the low level of selectivity for these receptors over $\mu$-OR is counter to the many observations across other GPCRs that allosteric modulators can selectively target closely related receptors that traditional orthosteric ligands have been unable to achieve (for review, see May et al., 2007; Keov et al., 2011). The idea of nonselectivity at allosteric sites has been previously seen with the muscarinic acetylcholine receptor (mAchR) family of five receptors that, like the opioid receptors, share a very high level of homology. The allosteric modulator $\mathrm{C}_{7 / 3}$-phth acts at all subtypes of $\mathrm{mAchRs}$, although it has the highest affinity for the $\mathrm{M}_{2} \mathrm{R} \mathrm{mAChR}$ (Christopoulos et al., 1999) and LY2033298 is a PAM at both $\mathrm{M}_{2} \mathrm{R}$ and $\mathrm{M}_{4} \mathrm{R}$ mAChRs (Chan et al., 2008; Valant et al., 2012). Indeed, recent crystallographic studies with mAchRs have found that the allosteric sites of these family members are quite homologous (Thal et al., 2016), giving a rational explanation for the difficulty in developing selective allosteric ligands for these receptors as well as orthosteric ligands; however, selectivity may arise from the cooperativity of allosteric ligands with orthosteric sites and their ligands. For example, an allosteric ligand may bind different receptors but show cooperativity with only the orthosteric site of one receptor, and this may, or may not, be dependent on the orthosteric ligand.

One of the most pressing questions to understand more completely the mechanism of the allosteric modulators and 

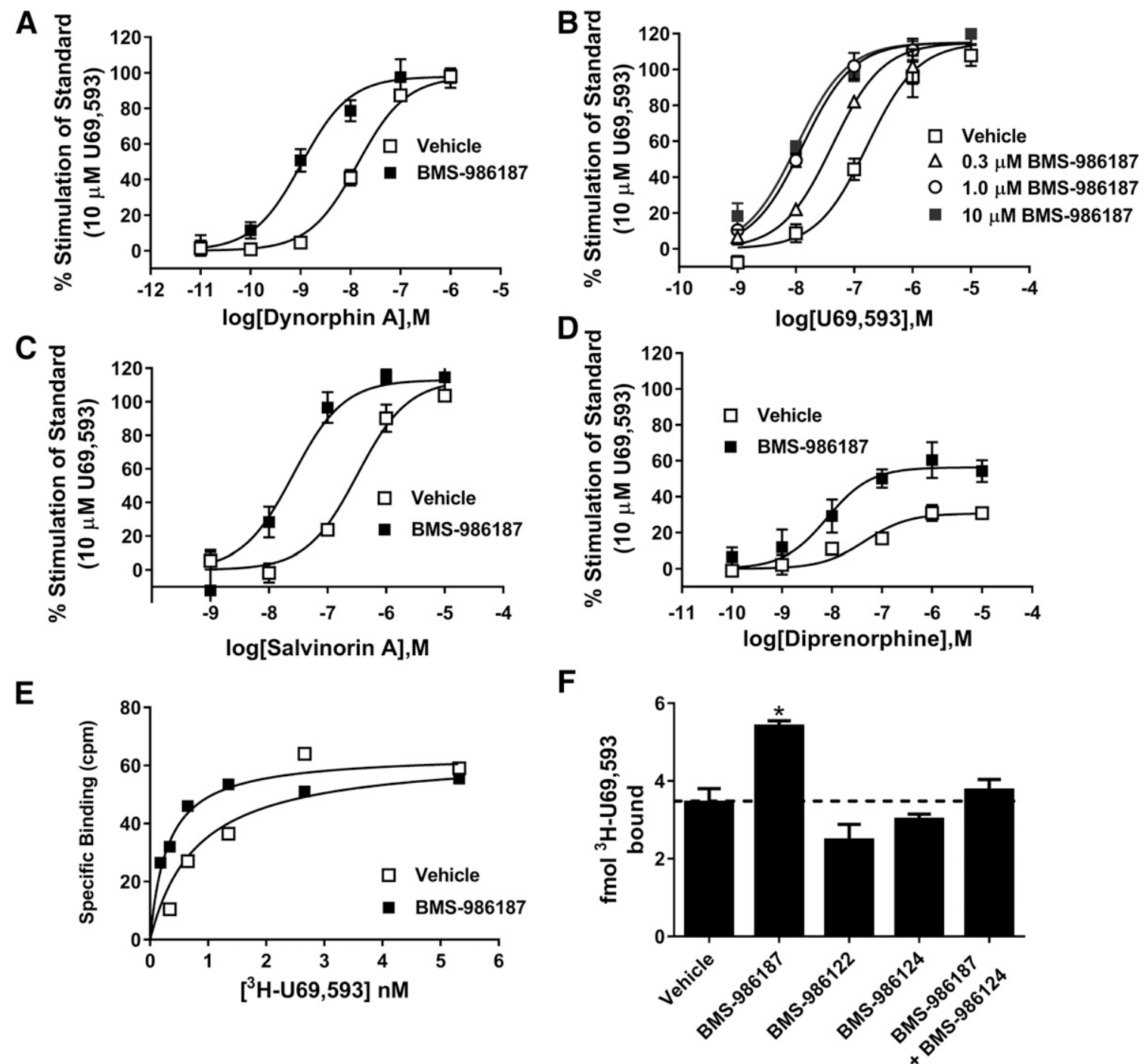

Fig. 7. BMS-986187 is a PAM at $\kappa$-OR. (A) Using CHO cells expressing $\kappa$-OR, the ability of dynorphin A (1-17) to active G protein as measured by the GTP $\gamma^{35} \mathrm{~S}$ binding assay was determined in the absence or presence of $10 \mu \mathrm{M}$ BMS-986187. Using the same cell membranes, concentration-response curves were generated for (B) U69,593, (C) salvinorin A, and (D) DPN in the presence of vehicle or $10 \mu \mathrm{M}$ BMS-986187. (E) Representative experiments (of four each in duplicate) showing the affinity but not maximal binding of ${ }^{3} \mathrm{H}-\mathrm{U} 69,593$ were enhanced in the presence of BMS-986187. (F) BMS-986122 or BMS-986124 did not alter the binding of ${ }^{3} \mathrm{H}-\mathrm{U} 69,593$ but blocked the PAM effect of BMS-986187. *Analysis by ANOVA followed by Tukey post hoc showed significant differences between BMS-986187 alone and all other conditions.

the rational design of modulators is identification of their binding site(s) on the opioid receptors. Comparisons of two recent and independent molecular dynamics simulations suggest that the binding of BMS-986122 at $\mu$-OR (Bartuzi et al., 2016) and BMS-986187 at $\delta$-OR (Shang et al., 2016) rely on the same residues at the top of TM domains 2 and 7 (Livingston and Traynor, 2017). Indeed, the striking similarity in theoretical binding pockets for these ligands at two different opioid receptors supports our pharmacologic evidence of a conserved site. In the proposed region, Tyr 2.64, His 7.36, and Ile 7.39 (numbers refer to Ballesteros-Weinstein generic numbering scheme) (Ballesteros and Weinstein, 1995) are conserved across $\mu$-OR, $\delta$-OR, and $\kappa$-OR. In particular, Tyr 2.64 may have an important role and is seen to undergo large conformational changes upon $\mu$-OR receptor activation when comparing the inactive and active crystal structures of this receptor (Manglik et al., 2012; Huang et al., 2015). It is also worth noting that Tyr 7.35 in $\kappa$-OR, an amino acid implicated in the putative allosteric sites on $\delta$-OR and $\mu$-OR (Bartuzi et al., 2016; Shang et al., 2016), is involved in hydrogen bond formation with the orthosteric antagonist JD-Tic (Wu et al., 2012), which could indicate that JD-Tic is bitopic and reaches into the allosteric site of $\kappa$-OR. This residue 7.35, as a Trp or Tyr, is crucial for the binding and function of allosteric modulators and agonistmediated conformational changes at a number of GPCRs (reviewed in Livingston and Traynor, 2017), including M1 (Abdul-Ridha et al., 2014), M2 (Jäger et al., 2007; Haga et al., 2012; Dror et al., 2013), M4 receptors (Thal et al., 2016), and $\beta 2 A R$ and M2R (DeVree et al., 2016).

The allosteric site for BMS-986122 and BMS-986187 does not appear to be conserved on NOPR as we failed to see allosteric activity of the ligands. Differences in amino-acid composition are found when comparing the reported putative allosteric sites in $\mu$-OR and $\delta$-OR with the same region of the NOPR. This finding is not surprising as NOPR shares the least amount of homology with the other opioid receptors, and 

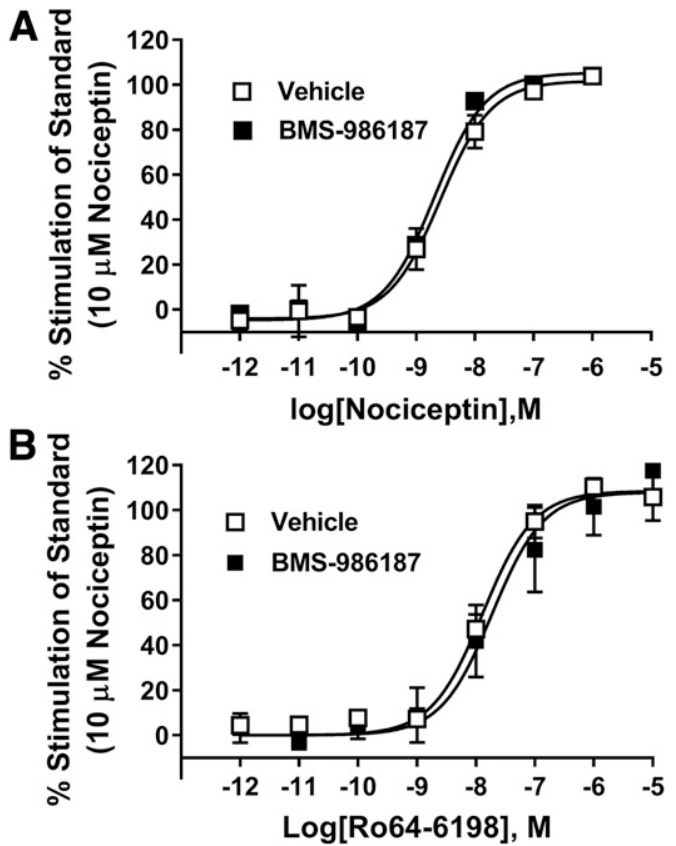

Fig. 8. BMS-986187 $(10 \mu \mathrm{M})$ failed to alter the potency of the NOPR agonists (A) nociceptin or (B) Ro-64-6198 to stimulate GTP $\gamma^{35}$ S binding in membranes from HEK293 cells stably expressing human NOPR. Data shown are means \pm S.E.M. from four experiments in duplicate fitted by linear regression with Hill slopes of unity using GraphPad Prism 6.01.

classically it has not been characterized as an opioid receptor owing to its inability to bind the antagonist naloxone (Cox et al., 2015). The orthosteric binding sites of the four opioid receptors are generally conserved but with one striking difference (reviewed in Cox, 2013). In $\mu$-OR, $\delta$-OR, and $\kappa$-OR, a His in TM6 is joined by a two-water-molecule bridge to the phenolic hydroxyl on $\mathrm{Tyr}^{1}$ of the opioid peptides or on the aromatic ring of small-molecule opioids, including naloxone. In NOPR, this His is replaced by Gln and so does not form the water bridge linking to the phenolic hydroxyl. Instead, NOPR ligands have a Phe in position 1 that is suggested to interact with a Tyr in TM3 via $\pi$-stacking (Thompson et al., 2012). This difference could account for the lack of cooperativity of NOPR orthosteric agonists with BMS-986122 and BMS986187. Nevertheless, it cannot be ruled out that these allosteric ligands might be modulators of NOPR but have much lower affinity so that higher concentrations are required or, owing to probe dependence, may exhibit cooperativity with ligands other than Ro64-6198 and the endogenous ligand nociceptin that we examined. For example, the CCR5 receptor negative allosteric modulator aplaviroc fully prevents binding of the chemokine CCR3 but has almost no effect on CCL5 binding (Watson et al., 2005). In addition, BMS-986187 and BMS-986122 might be SAMs at NOPR, but without a known PAM for NOPR, testing this is not currently possible.

Few examples of endogenous allosteric modulators for GPCRs have been reported (for review, see van der Westhuizen et al., 2015) including dynorphin A, a putative allosteric modulator of the $\mathrm{M}_{2} \mathrm{mAChR}$ ( $\mathrm{Hu}$ and El-Fakahany, 1993); glutathione, an allosteric ligand for the calcium-sensing receptor (Wang et al., 2006; Broadhead et al., 2011); and lipoxin A4, which has been proposed as an endogenous cannabinoid receptor modulator (Pamplona et al., 2012). Since the evidence presented suggests that the three classic members of the opioid family of receptors share a similar allosteric binding site, it is tempting to speculate that this may be caused by evolutionary pressure from an endogenous allosteric modulator that binds the opioid receptors, although this may be vestigial.

\section{Authorship Contributions}

Participated in research design: Livingston, Traynor.

Conducted experiments: Livingston, Stanczyk, Burford, Alt.

Contributed new reagents or analytic tools: Burford, Alt.

Performed data analysis: Livingston, Canals, Traynor.

Wrote or contributed to the writing of the manuscript: Livingston, Traynor.

\section{References}

Abdul-Ridha A, Lane JR, Mistry SN, López L, Sexton PM, Scammells PJ, Christopoulos A, and Canals M (2014) Mechanistic insights into allosteric structurefunction relationships at the M1 muscarinic acetylcholine receptor. $J$ Biol Chem 289:33701-33711.

Ballesteros JA and Weinstein H (1995) Integrated methods for the construction of three-dimensional models and computational probing of structure-function relations in G protein-coupled receptors. Methods Neurosci 25:366-428.

Bartuzi D, Kaczor AA, and Matosiuk D (2016) Interplay between two allosteric sites and their influence on agonist binding in human $\mu$ opioid receptor. $J$ Chem Inf Model 56:563-570.

Bisignano P, Burford NT, Shang Y, Marlow B, Livingston KE, Fenton AM, Rockwell K, Budenholzer L, Traynor JR, Gerritz SW, et al. (2015) Ligand-based discovery of a new scaffold for allosteric modulation of the $\mu$-opioid receptor. $J$ Chem Inf Model 55:1836-1843.

Broadhead GK, Mun HC, Avlani VA, Jourdon O, Church WB, Christopoulos A, Delbridge L, and Conigrave AD (2011) Allosteric modulation of the calcium-sensing receptor by gamma-glutamyl peptides: inhibition of PTH secretion, suppression of intracellular cAMP levels, and a common mechanism of action with L-amino acids. J Biol Chem 286:8786-8797.

Burford NT, Clark MJ, Wehrman TS, Gerritz SW, Banks M, O'Connell J, Traynor JR, and Alt A (2013) Discovery of positive allosteric modulators and silent allosteric modulators of the $\mu$-opioid receptor. Proc Natl Acad Sci USA 110:10830-10835.

Burford NT, Livingston KE, Canals M, Ryan MR, Budenholzer LM, Han Y, Shang Y, Herbst JJ, O'Connell J, Banks M, et al. (2015) Discovery, synthesis, and molecular pharmacology of selective positive allosteric modulators of the $\delta$-opioid receptor. $J$ Med Chem 58:4220-4229.

Chan WY, McKinzie DL, Bose S, Mitchell SN, Witkin JM, Thompson RC, Christopoulos A, Lazareno S, Birdsall NJM, Bymaster FP, et al. (2008) Allosteric modulation of the muscarinic M4 receptor as an approach to treating schizophrenia. Proc Natl Acad Sci USA 105:10978-10983.

Chen Y, Mestek A, Liu J, Hurley JA, and Yu L (1993) Molecular cloning and functional expression of a mu-opioid receptor from rat brain. Mol Pharmacol 44:8-12. Christopoulos A, Changeux J-P, Catterall WA, Fabbro D, Burris TP, Cidlowski JA, Olsen RW, Peters JA, Neubig RR, Pin J-P, et al. (2014) International Union of Basic and Clinical Pharmacology. XC. multisite pharmacology: recommendations for the nomenclature of receptor allosterism and allosteric ligands. Pharmacol Rev 66:918-947.

Christopoulos A and Kenakin T (2002) G protein-coupled receptor allosterism and complexing. Pharmacol Rev 54:323-374.

Christopoulos A, Sorman JL, Mitchelson F, and El-Fakahany EE (1999) Characterization of the subtype selectivity of the allosteric modulator heptane-1,7-bis-(dimethyl-3'-phthalimidopropyl) ammonium bromide (C7/3-phth) at cloned muscarinic acetylcholine receptors. Biochem Pharmacol 57:171-179.

Clark MJ, Harrison C, Zhong H, Neubig RR, and Traynor JR (2003) Endogenous RGS protein action modulates $\mu$-opioid signaling through Galphao: effects on adenylyl cyclase, extracellular signal-regulated kinases, and intracellular calcium pathways. J Biol Chem 278:9418-9425.

Clark MJ, Linderman JJ, and Traynor JR (2008) Endogenous regulators of G protein signaling differentially modulate full and partial mu-opioid agonists at adenyly cyclase as predicted by a collision coupling model. Mol Pharmacol 73:1538-1548. Conn PJ, Christopoulos A, and Lindsley CW (2009) Allosteric modulators of GPCRs: a novel approach for the treatment of CNS disorders. Nat Rev Drug Discov 8:41-54

Cox BM (2013) Recent developments in the study of opioid receptors. Mol Pharmacol 83:723-728.

Cox BM, Christie MJ, Devi L, Toll L, and Traynor JR (2015) Challenges for opioid receptor nomenclature: IUPHAR Review 9. Br J Pharmacol 172:317-323.

DeVree BT, Mahoney JP, Vélez-Ruiz GA, Rasmussen SGF, Kuszak AJ, Edwald E, Fung J-J, Manglik A, Masureel M, Du Y, et al. (2016) Allosteric coupling from G protein to the agonist-binding pocket in GPCRs. Nature 535:182-186.

Dror RO, Green HF, Valant C, Borhani DW, Valcourt JR, Pan AC, Arlow DH, Canals M, Lane JR, Rahmani R, et al. (2013) Structural basis for modulation of a G-protein-coupled receptor by allosteric drugs. Nature 503:295-299.

Fenalti G, Giguere PM, Katritch V, Huang X-P, Thompson AA, Cherezov V, Roth BL, and Stevens RC (2014) Molecular control of $\delta$-opioid receptor signalling. Nature 506:191-196.

Haga K, Kruse AC, Asada H, Yurugi-Kobayashi T, Shiroishi M, Zhang C, Weis WI, Okada T, Kobilka BK, Haga T, et al. (2012) Structure of the human M2 muscarinic acetylcholine receptor bound to an antagonist. Nature 482:547-551. 
$\mathrm{Hu} \mathrm{J}$ and el-Fakahany EE (1993) Allosteric interaction of dynorphin and myelin basic protein with muscarinic receptors. Pharmacology 47:351-359.

Huang W, Manglik A, Venkatakrishnan AJ, Laeremans T, Feinberg EN, Sanborn AL, Kato HE, Livingston KE, Thorsen TS, Kling RC, et al. (2015) Structural insights into $\mu$-opioid receptor activation. Nature 524:315-321.

Jäger D, Schmalenbach C, Prilla S, Schrobang J, Kebig A, Sennwitz M, Heller E, Tränkle C, Holzgrabe U, Höltje H-D, et al. (2007) Allosteric small molecules unveil a role of an extracellular E2/transmembrane helix 7 junction for $\mathrm{G}$ protein-coupled receptor activation. J Biol Chem 282:34968-34976.

Katritch V, Fenalti G, Abola EE, Roth BL, Cherezov V, and Stevens RC (2014) Allosteric sodium in class A GPCR signaling. Trends Biochem Sci 39:233-244.

Keov P, Sexton PM, and Christopoulos A (2011) Allosteric modulation of G proteincoupled receptors: a pharmacological perspective. Neuropharmacology 60:24-35.

Leach K, Loiacono RE, Felder CC, McKinzie DL, Mogg A, Shaw DB, Sexton PM, and Christopoulos A (2010) Molecular mechanisms of action and in vivo validation of an M4 muscarinic acetylcholine receptor allosteric modulator with potential antipsychotic properties. Neuropsychopharmacology 35:855-869.

Leach K, Sexton PM, and Christopoulos A (2007) Allosteric GPCR modulators: taking advantage of permissive receptor pharmacology. Trends Pharmacol Sci 28 $382-389$

Lee KO, Akil H, Woods JH, and Traynor JR (1999) Differential binding properties of oripavines at cloned mu- and delta-opioid receptors. Eur $J$ Pharmacol 378: $323-330$.

Lin H, Higgins P, Loh HH, Law P-Y, and Liao D (2009) Bidirectional effects of fentanyl on dendritic spines and AMPA receptors depend upon the internalization of mu opioid receptors. Neuropsychopharmacology 34:2097-2111.

Liu W, Chun E, Thompson AA, Chubukov P, Xu F, Katritch V, Han GW, Roth CB, Heitman LH, IJzerman AP, et al. (2012) Structural basis for allosteric regulation of GPCRs by sodium ions. Science 337:232-236.

Livingston KE and Traynor JR (2014) Disruption of the $\mathrm{Na}+$ ion binding site as a mechanism for positive allosteric modulation of the mu-opioid receptor. Proc Natl Acad Sci USA 111:18369-18374

Livingston KE, and Traynor JR (2017) Allostery at opioid receptors: modulation with small molecule ligands. Br J Pharmacol DOI: 10.1111/bph.13823 [published ahead of print].

Manglik A, Kruse AC, Kobilka TS, Thian FS, Mathiesen JM, Sunahara RK, Pardo L, Weis WI, Kobilka BK, and Granier S (2012) Crystal structure of the $\mu$-opioid receptor bound to a morphinan antagonist. Nature 485:321-326.

May LT, Leach K, Sexton PM, and Christopoulos A (2007) Allosteric modulation of G protein-coupled receptors. Annu Rev Pharmacol Toxicol 47:1-51.

Pamplona FA, Ferreira J, Menezes de Lima O, Jr, Duarte FS, Bento AF, Forner S, Villarinho JG, Bellocchio L, Wotjak CT, Lerner R, et al. (2012) Anti-inflammatory lipoxin A4 is an endogenous allosteric enhancer of CB1 cannabinoid receptor. Proc Natl Acad Sci USA 109:21134-21139.
Pert C and Snyder S (1974) Opiate receptor binding of agonists and antagonists affected differentially by sodium. Mol Pharmacol 1:868-879.

Pert CB, Pasternak G, and Snyder SH (1973) Opiate agonists and antagonists discriminated by receptor binding in brain. Science 182:1359-1361.

Shang Y, Yeatman HR, Provasi D, Alt A, Christopoulos A, Canals M, and Filizola M (2016) Proposed mode of binding and action of positive allosteric modulators at opioid receptors. ACS Chem Biol 11:1220-1229.

Stevens CW (2009) The evolution of vertebrate opioid receptors. Front Biosci 14: $1247-1269$

Szekeres PG and Traynor JR (1997) Delta opioid modulation of the binding of guanosine-5'-O-(3-[35S]thio)triphosphate to NG108-15 cell membranes: characterization of agonist and inverse agonist effects. J Pharmacol Exp Ther 283:1276-1284.

Thal DM, Sun B, Feng D, Nawaratne V, Leach K, Felder CC, Bures MG, Evans DA, Weis WI, Bachhawat P, et al. (2016) Crystal structures of the M1 and M4 muscarinic acetylcholine receptors. Nature 531:335-340.

Thompson AA, Liu W, Chun E, Katritch V, Wu H, Vardy E, Huang XP, Trapella C, Guerrini R, Calo G, et al. (2012) Structure of the nociceptin/orphanin FQ receptor in complex with a peptide mimetic. Nature 485:395-399.

Traynor JR, Corbett AD, and Kosterlitz HW (1987) Diprenorphine has agonist activity at opioid kappa-receptors in the myenteric plexus of the guinea-pig ileum. Eur J Pharmacol 137:85-89.

Traynor JR and Nahorski SR, Sr (1995) Modulation by mu-opioid agonists of guanosine-5'-O-(3-[ $\left.{ }^{35} \mathrm{~S}\right]$ thio)triphosphate binding to membranes from human neuroblastoma SH-SY5Y cells. Mol Pharmacol 47:848-854.

Valant C, Felder CC, Sexton PM, and Christopoulos A (2012) Probe dependence in the allosteric modulation of a $\mathrm{G}$ protein-coupled receptor: implications for detection and validation of allosteric ligand effects. Mol Pharmacol 81:41-52.

van der Westhuizen ET, Valant C, Sexton PM, and Christopoulos A (2015) Endogenous allosteric modulators of G protein-coupled receptors. J Pharmacol Exp Ther 353:246-260.

Wang M, Yao Y, Kuang D, and Hampson DR (2006) Activation of family C G-proteincoupled receptors by the tripeptide glutathione. J Biol Chem 281:8864-8870.

Watson C, Jenkinson S, Kazmierski W, and Kenakin T (2005) The CCR5 receptorbased mechanism of action of 873140 , a potent allosteric noncompetitive HIV entry inhibitor. Mol Pharmacol 67:1268-1282.

Wu H, Wacker D, Mileni M, Katritch V, Han GW, Vardy E, Liu W, Thompson AA, Huang XP, Carroll FI, et al. (2012) Structure of the human $\kappa$-opioid receptor in complex with JDTic. Nature 485:327-332.

Address correspondence to: John R. Traynor, Department of Pharmacology, University of Michigan, 1150 West Medical Center Drive, 2301 MSRB III, Ann Arbor, MI 48109. E-mail: jtraynor@umich.edu 